\title{
(息)
}

Citation:

Olanipekun, AO and Omotayo, T (2021) Review of the Use of Corporate Social Responsibility (CSR) Tools. Sustainable Production and Consumption, 27. pp. 425-435. ISSN 2352-5509 DOI: https://doi.org/10.1016/j.spc.2020.11.012

Link to Leeds Beckett Repository record:

https://eprints.leedsbeckett.ac.uk/id/eprint/7263/

Document Version:

Article (Accepted Version)

Creative Commons: Attribution-Noncommercial-No Derivative Works 4.0

The aim of the Leeds Beckett Repository is to provide open access to our research, as required by funder policies and permitted by publishers and copyright law.

The Leeds Beckett repository holds a wide range of publications, each of which has been checked for copyright and the relevant embargo period has been applied by the Research Services team.

We operate on a standard take-down policy. If you are the author or publisher of an output and you would like it removed from the repository, please contact us and we will investigate on a case-by-case basis.

Each thesis in the repository has been cleared where necessary by the author for third party copyright. If you would like a thesis to be removed from the repository or believe there is an issue with copyright, please contact us on openaccess@leedsbeckett.ac.uk and we will investigate on a case-by-case basis. 


\section{Review of the Use of Corporate Social Responsibility (CSR) Tools}

*Dr. Ayokunle Olubunmi Olanipekun

Postdoctoral Research Fellow,

Massey University,

Auckland, New Zealand

Email: olanipekun1439@yahoo.com; A.Olanipekun@massey.ac.nz

Dr. Temitope Omotayo

Senior Lecturer,

School of Built Environment, Engineering and Computing

Leeds Beckett University, Leeds, Great Britain

Email: t.s.omotayo@leedsbeckett.ac.uk

\section{Review of the Use of Corporate Social Responsibility (CSR) Tools}

\section{Abstract}

There are an increasing number of corporate social responsibility (CSR) reporting tools that are evolving. As a result, it has become chaotic and complicated for practitioners to select the most appropriate one for CSR reporting. To address the problem, previous studies have classified the CSR reporting tools into frameworks, standards and, ratings and indices classes for easy comprehension and application in practice. However, no study has focused on revealing the use of CSR reporting tools based on this classification. This study employed researchers' perspectives through a systematic review of journal papers published between 2001-2016 to reveal the use of CSR reporting tools based on their classifications. The findings revealed that the GRI tool in the framework class is widely implemented, but also associated with many problems that impact CSR reporting in practice. Also, there are new aspects where the tool could be used are for CSR learning in organisations and CSR regulation. Furthermore, the CSR reporting tools in the standards, ratings and indices classes are not commonly implemented for CSR reporting thereby attracting less researcher interest. The study concluded by linking the research and practice of the use of CSR reporting tools in different classes. The study has implications for CSR reporters who use CSR reporting tools in the frameworks, standards, and ratings and indices classes.

\section{Keywords}

Corporate Social Responsibility tools; Frameworks; Standards; Ratings and indices, GRI

\section{Introduction}

Globally, the increasingly adverse impact of businesses on the environment and ecosystem is often experienced in the form of climate change problems, enormous resource consumption, 
and greenhouse gas emission (GHG) (Alazzani et al., 2013; Dumay et al., 2010). As a result, the practice of sustainability has shifted to address and reflect the ways businesses are carried out. In an attempt to exemplify and address sustainability concerns, businesses are obliged to implement corporate social responsibility (CSR) (Toppinen et al., 2012). As a derivative of sustainability (Zinenko et al., 2015b), CSR is the modern way of managing businesses by reflecting business actions for the benefit of society, care for the natural environment and relations with various groups of stakeholders (Marakova et al., 2015). Also, it is an effort to integrate and reinforce positive social and ecological impacts of business activities to its surroundings, and vice versa, and to reduce the negative ones (Tokarčíková et al., 2014). When implemented, socially responsible actions are selfless, such as the participation of businesses in community tasks without legal or commercial motivation, as well as the implementation of help projects to meet dire needs (Tokarčíková et al., 2014).

When implementing CSR practices, CSR reporting is expected of businesses (or reporting organisations) to provide information on economic, environmental and social performances in order to allow stakeholders, whose interests are tied to the reporting entities, to assess the ways in which these entities contribute to sustainable development (Yongvanich et al., 2004). According to Brown, De Jong, and Lessidrenska (2009), CSR reporting is a norm of socially responsible business, which is done in a visible, accountable and transparent format using CSR reporting tools (Adams et al., 2004; Toppinen et al., 2013). Therefore, CSR reporting tools are used by businesses to document implemented CSR practices and the impacts on stakeholder interests. A CSR reporting tool can be conceptualised in three forms. Firstly, it is both methodical and standardised means through which the CSR practices are communicated accountably and transparently (Ayuso et al., 2016; Turner et al., 2006). Secondly, it is an inducement of both systematic and visible implementation of CSR practices (MoratisandWidjaja, 2014). Thirdly, it is a means of evaluation of CSR performance, for instance, against internally benchmarked objectives (Siew, 2015).

Meanwhile, as CSR reporting tools have evolved, and their numbers increased, there has been a growing number of studies on the subject. Studies can be classified into those focusing on frameworks (Turner et al., 2006), standards (Tschopp et al., 2014), and ratings and indices (Dumay et al., 2010). Frameworks are the classes of CSR reporting tools that provide principles, initiatives and guidelines for CSR reporting (Siew, 2015a). A common example is the Global Reporting Initiative (GRI) which is widely used for CSR reporting in practice (Chen et al., 2015). Standards are like frameworks in guiding CSR reporting efforts, but in 
the form of formal documentation that spell out requirements for achieving social responsibility (Göbbels et al., 2003b). An example is the International Standards Organisation (ISO 26000), which is gaining acceptance among CSR reporters. The ratings and indices enable third-party certification of the level of social responsibility in business organisations (Tam et al., 2018) and sustainability performance in buildings and communities (Sharifi et al., 2013). Given the increasing number of CSR reporting tools, research has been helpful to associate those having similar characteristics under a few classifications that can easily be comprehended and applied in practice (Diez-Cañamero et al., 2020), as demonstrated in Siew (2015a). However, based on the existing classifications, the extent to which CSR reporting tools are applicable, or can be used, is not known.

This study was aimed at investigating the use of CSR reporting tools based on their classifications. This provided a more comprehensive and harmonised knowledge of the collective use of CSR reporting tools. It is a departure from the existing practice among researchers to analyse CSR reports only - a practice that merely reveals details of the use of CSR reporting tools individually (Chantziaras et al., 2020; Gray et al., 1995). Analysing CSR reporting tools based on their classifications may shed new light on the collective use of tools. Departing from the analysis of CSR reports, this study employed researchers' accounts through the systematic literature review of journal publications to achieve the aim. The researchers' accounts granted the opportunity to make new recommendations for the use of CSR reporting tools according to the classifications. Also, the systematic literature review was approached in two stages, comprising sourcing and screening of published literature in a large database. This provided a unique research method that could be replicated by students and researchers in future related research. Finally, this research was organised as follows. Following an initial conceptual definition and review of CSR reporting tools, the systematic approach to selecting and analysing research works was stated. Thereafter, the findings were reported based on different classes of CSR reporting tools. Lastly, the findings were discussed, followed by the conclusion and recommendations.

\section{Review of CSR reporting tools}

CSR reporting tools are universal guidelines that are developed and periodically updated to level social responsibility informational reporting asymmetries (Gingerich, 2010). Primarily, they provide comprehensive information about implemented CSR practices to stakeholders whose interests are tied to the reporting organisations (Linneberg et al., 2014; Lock et al., 2015). Over time, CSR reporting tools have evolved, and their numbers have increased 
immensely. See relevant other researchers (Angelakoglou et al., 2015; Li et al., 2017; Sharifi et al., 2013; Siew, 2015a; Tam et al., 2018) for the identification of these tools. Likewise, there are many organisations and institutions responsible for developing the tools, and this results in the production of tools that are uniquely different. According to Diez-Cañamero et al. (2020), these reasons have resulted in a chaotic universe of CSR reporting tools. For instance, some CSR reporting tools might be more applicable universally (e.g. GRI; (Alazzani et al., 2013)), while others might only be regionally applicable. Some might focus on specific sector CSR reporting, while others might be applicable across multiple sectors. CSR can be divided into social, economic and environmental dimensions (GonzálezRodríguez et al., 2015; Nikolaou et al., 2019) and some CSR reporting tools might be focused on one or more CSR dimensions than the others. Business organisations often find it complicated to select from the universe the appropriate CSR reporting tools that match their interests (Diez-Cañamero et al., 2020). At the same time, the business organisations find it difficult to compare CSR reports. Previous studies have attempted to address this problem by classifying CSR reporting tools based on unique characteristics that are common to them (e.g. (Cohen, 2017; Zinenko et al., 2015a)). The common classification of CSR reporting tools are frameworks, standards and, ratings and indices classes (e.g. (Siew, 2015a)) and are described as follows.

The typical CSR reporting tools in the framework class are briefly described below.

- The United Nations Global Compact (UNGC) was launched in the year 2000 as a framework consisting of ten principles in the areas of human rights, labour, environment and corruption to govern socially responsible actions and reporting in business organisations (Kolk, 2011; Tschopp et al., 2014). The governance functions of the UNGC are performed through the leaders' summit, local networks, annual local networks forum, and global compact offices (Tschopp et al., 2014).

- The GRI issued first guidelines in 1999 and revised them in 2000 and 2002. The G3 guidelines were released in 2006 (Tschopp et al., 2014), while the latest (G4) that was produced in May 2013 proposed changes to themes such as Anti-Corruption and Greenhouse Gas (GHG) Emissions (Siew, 2015a). The mission of the GRI is to become the globally accepted standard in CSR reporting (Tschopp et al., 2014) by promoting organisational transparency and accountability as well as stakeholder engagement (Vigneau et al., 2015). For instance, the G3 can be used in organisations of any size, sector, or location (Tschopp et al., 2014). Also, the GRI has reporting norms on what to report and how to report at different application levels (Tschopp et al., 2014; Vigneau et al., 2015). Therefore, organisations of different sizes, resources, experience, or goals may choose a level that best meets their needs (Tschopp et al., 2014). The application levels are designated A, B, or C, with a $C$ level requiring the least disclosure (Tschopp et al., 2014).

The typical CSR reporting tools in the standards class are briefly described below. 
- The Accountability Assurance (AA1000) tool was launched by the Institute of Social and Ethical Accountability (ISEA) as a voluntary standard for social and ethical accounting, auditing and reporting in 1999 (Tschopp et al., 2014). It was launched with the aim to address the public's distrust in human rights reports, community and economic issues, and to enhance the social and ethical performance of organisations (Göbbels et al., 2003b). Therefore, the AA1000 can be used to define sustainability goals and targets in business organisations and the measurement of progress against the targets (Tschopp et al., 2014).

- The Social Accountability (SA8000) tool was introduced by the Council on Economic Priorities Accreditation Agency (CEPAA) in 1997 to ensure both ethical sourcing of products and goods and workplace conditions globally (Göbbels et al., 2003b). The tool is used not only for reporting employee protection and empowerment practices, but also practices relating to child labour, forced and compulsory labour, health and safety, and freedom of association (Siew, 2015a).

- The ISO 26000 is a tool that broadly covers CSR practices in government agencies and other organisations as well as corporations (Tschopp et al., 2014). The primary purpose of the ISO 26000 standard is to provide practical guidance on implementing and integrating social responsibility in organisations, as well as external reporting of implemented CSR practices (Tschopp et al., 2014)

The CSR reporting tools in the ratings and indices class basically indicate the social responsibility contributions of businesses to sustainable development and Diez-Cañamero et al. (2020) further classified them into indexes, rankings and ratings typology that make them more useful in business corporations (Table 1).

Table 1: Typology of CSR reporting tools in ratings and indices class

\begin{tabular}{ll}
$\begin{array}{l}\text { CSR reporting tools in ratings and indices } \\
\text { class }\end{array}$ & Typology \\
\hline DJSI World & Index \\
ECPI World ESG Equity Index & Index \\
ESI Excellence Global & Index \\
Euronext Vigeo Eiris World 120 & Index \\
FTSE4Good Developed Index & Index \\
GCX & Index \\
GSLI & Index \\
MSCI World ESG Leaders Index & Index \\
STOXX Global ESG Leaders Index & Index \\
Sustainalytics' ESG Risk Rating & Index \\
Global CR RepTrak 100 & Ranking \\
The Sustainability Yearbook & Ranking \\
World's Most Sustainable Corporations- & \\
Global 100 & Ranking \\
ISS-oekom Corporate Rating & Rating \\
Supplier CSR Rating & Rating \\
\hline
\end{tabular}

Source: Diez-Cañamero et al. (2020) 
It could be seen that most indexes aim clearly at shareholders, investors and executives (Diez-Cañamero et al., 2020; Li et al., 2017). By contrast, ratings and rankings have a multistakeholder approach, and they are more open tools, which can theoretically be used by any stakeholder (Diez-Cañamero et al., 2020). Furthermore, the reporting tools in this class can be used for assessing sustainability performance in buildings and communities (Tam et al., 2018). The typical ones are briefly described below.

- Dow Jones Sustainability Index (DJSI) method was first launched in 1999 as a global sustainability benchmark (Siew, 2015a) for assessing aspects such as environmental reporting, environmental policy/management system, operational eco-efficiency and climate strategy in business corporations (Angelakoglou et al., 2015).

- The Financial Times Stock Exchange (FTSE4Good) index aims to provide investors a means by which they could identify and invest in corporations that meet the minimum requirement of socially responsible practices (Angelakoglou et al., 2015). To be included in the FTSE4Good Index Series, business corporations must be able to meet the requirements in five key areas that include working towards environmental sustainability, upholding and supporting universal human rights, ensuring good supply chain labour standards, countering bribery and mitigating climate change (Siew, 2015a).

- Leadership in Energy and Environmental Design (LEED) are sustainability assessment tools developed by the United States Green Building Council (USGBC). The LEED rating system focuses primarily on green building practices while LEED-ND (Neighbourhood Development) places emphasis on the site selection, design, and construction elements that bring buildings and infrastructure together into a neighbourhood (Sharifi et al., 2013).

- The Building Research Establishment Environmental Assessment Method (BREEAM) for communities, is an independent, third-party assessment certification tool to help planners and developers take account of the full range of issues to measure and independently certify the sustainability of project proposals at the planning stage of the development process ( $\mathrm{Li}$ et al., 2017; Sharifi et al., 2013).

- Comprehensive Assessment System for Built Environment Efficiency (CASBEE) for urban development was developed by the Japan Sustainable Building Consortium (JSBC) in 2004 as an independent assessment certification tool developed to contribute to enhancing sustainability in urban plans (Sharifi et al., 2013).

- $\quad H Q E^{2} R$ was designed by the European Union as a methodological framework to provide an integrated approach with adapted methods and tools used by local municipalities and their partners in their neighbourhood regeneration and urban management projects (Sharifi et al., 2013; Tam et al., 2018).

Analysing CSR reporting tools according to their classifications, offered the opportunity to make new recommendations about the collective use of the tools. This study employed researchers' accounts through literature review to achieve this objective.

\section{Methods}

We (the authors) purposely employed the systematic review method to collect several previous publications focusing on CSR reporting and analyse them to deduce the use of CSR reporting tools based on their classifications. As shown in Figure 1, we employed a two-stage 
systematic review research method. The first stage was the sourcing of data on CSR reporting tools, which also formed the (initial) unit of analysis. To obtain data, we focused on academic journal publications only. Our reasons are: (1) to be able to use a similar methodology in exploring the publications (Mok et al., 2015), and (2) to increase research rigour by sourcing data from more rigorous sources (Olanipekun et al., 2017). We sourced for the journal publications from the Scopus database like Gupta et al. (2011). The database is powerful and effective for systematic literature search (Sartor et al., 2016) and it encompasses publications from other databases such as Emerald, Elsevier, Springer, Willey, Taylor \& Francis, JStor (Morioka et al., 2016). Journal publications are textual information. Therefore, within the database, we started by selecting the keywords to retrieve only the publications vital to the study. In line with the aim of the study, our initial choice was "corporate social responsibility reporting tools." However, this keyword yielded no result in the Google Scholar database. After that, we applied an appropriate Boolean operator in this manner "corporate social responsibility reporting" AND "tools." This combination yielded results in the same database. However, the second string "tools" is barely used in the context we aimed for in the publications. Most often, the term appears in the methodology to describe the analytical tools.

Figure 1: Illustration of the research method

Consequently, we decided to choose "corporate social responsibility reporting" as the keyword to perform our search in the database. As illustrated in Figure 2, this provided the conceptual avenue for obtaining information regarding the use of CSR reporting tools (Campopiano et al., 2015). Meanwhile, we also took into consideration the interchanging use of "corporate social responsibility reporting" and "corporate social responsibility disclosure" in the application of the keyword for publication retrieval in the Scopus database. We executed the keyword as a search rule under the "article title/abstract/keywords" field of Scopus, and with the document type of "article or review." We included review publications to provide a conceptual, comprehensive and detailed map of research in the field (Sartor, et al., 2016). Also, we restricted the language of use to the English language because it is the language embraced by most scientific studies (Jones, Hillier, et al., 2015). A total of 2102 publications were retrieved and downloaded into Endnote after a systematic search to conclude the first stage.

Figure 2: Illustration of nexus between CSR reporting and CSR reporting tools 
The second stage started with downloading the retrieved publications. Afterwards, we were conscious to realise that not all of them would be useful. In such a case, Sartor et al. (2016) suggested a preliminary but cursory review of documents to eliminate the non-useful ones. Firstly, we removed the non-journal publications after checking for the publication type in all of them. Secondly, we removed one or more of the publications downloaded twice or more. Thirdly, we carried out a brief review of the abstracts. We used the review process to streamline the initially retrieved publications to retain only those focusing on describing the use of different CSR reporting tools. By streamlining, we excluded publications that focused on CSR reporting practices only, and not CSR reporting tools. In line with the earlier mentioned classification (Siew, 2015a), we looked for the descriptors of CSR reporting tools such as "frameworks" or "guidelines" or "models" or "standards or "ratings" or "indices" Also, we excluded the publications that merely mentioned their findings on CSR reporting tools. Finally, we retained 81 journal publications for further analysis. We employed the content analysis method for analysis of the publications. As a widely accepted method of obtaining and analysing data in studies about CSR reporting practices (Toppinen \& Korhonen-Kurki, 2013), it assisted in condensing and providing a broad description of the uses of CSR reporting tools in different classes (Elo et al., 2008). To enhance the inferential quality of findings, we profiled the selected publications as follows.

\subsection{Profile of selected publications}

As suggested previously, we analysed 81 journal publications. They covered a period of 16 years, from 2001 - 2016. The average number of publications between 2001 and 2008 was around 1.87. Since 2008, the number of publications per year was more than two, and since 2011, the number of publications per year steadily increased. As a result, we believed that the period covered captured relatively recent history behind most recent publications to determine whether there are trends regarding the use of CSR reporting tools that may be relevant today. Furthermore, the publications were mainly sourced from the social responsibility management domains (Table 2). Of the nine journals that had two or more publications, five of them (Numbers $1 ; 2 ; 4 ; 5 \& 6$ ) are commonly aimed at publishing research on improving ethics and social responsibility practices. Also, three of them focused on the sustainability domain (Numbers $3 ; 7 \& 8$ ), while number 2 combined social responsibility and sustainability domains. Therefore, this analysis reinforced the contribution of social responsibility practices to achieve sustainability objectives (Zhang et al., 2019).

Table 2: Distribution of selected publications in journals 


\begin{tabular}{llc}
\hline Number & Journals & Number of papers \\
\hline 1 & Journal of Business Ethics & 7 \\
& Corporate $\quad$ Social Responsibility $\quad$ and & \\
2 & Environmental Management & 4 \\
3 & Journal of Cleaner Production & 4 \\
4 & Social Responsibility Journal & 3 \\
5 & Business Ethics: A European Review & 2 \\
& Corporate Communications: An International & 2 \\
6 & Journal & 2 \\
7 & Ecological Indicators & 2 \\
8 & Environmental Quality Management & 2 \\
9 & International Journal of Production Economics & 53 \\
10 & Others (Less than 2 publications per journal) & 81
\end{tabular}

\subsection{Profile of CSR reporting tools}

This study focused on the use of CSR reporting tools. Therefore, it was necessary to identify the CSR reporting tools that were reported in the selected publications. Also, the appendix shows tables summarising the number of publications reporting individual tools. It could be seen that the GRI tool in the framework class is reported in sixty-four (64) publications, distantly followed by the ISO 26000 tool in the standards class in eight (8) publications. In fact, all the other CSR reporting tools such as the UNGC and International Integrated Reporting Council (IIRC) framework in the framework class, AA1000 and ISO14001 in the standards class and the BREAM, CASBEE, Green Star and LEED in the rating and indices class are reported in less than ten publications irrespective of the class. It should be noted that most of the publications reported the use of more than one CSR reporting tool.

\section{Results}

The content analysis of the 64 publications revealed two evolving uses of the GRI tool, which are yet to be established in many business organisations. These are for regulation mechanisms and internal learning in organisations and are explained in the following section. Furthermore, the content analysis revealed the problems associated with the use of the GRI tool for CSR reporting in organisations. Identifying and describing the problems may help to develop strategies for overcoming them. Seventeen publications reported the CSR reporting 
tools in the standards class. Based on the content analysis, the commonly reported CSR reporting tools in this class are the ISO 26000 and AA 10000. The analysis also provided information useful for the practical implementation of CSR reporting tools in this class. Seventeen publications reported the CSR reporting tools in the ratings and indices class. From the analysis, CSR reporting tools for evaluating sustainability performance in buildings and communities such as BREEAM are commonly reported. The analysis also revealed how the tools in this class complement the tools in the framework class and, their application at the community levels.

\subsection{Frameworks: Evolving uses of the GRI tool}

\subsubsection{Regulation mechanism}

The nexus between CSR reporting tools and legislation seems to be converging (Theron et al., 2012). As a result, many studies agreed that the GRI tool could become the mechanism for regulating CSR practices in organisations (Alonso-Almeida et al., 2014; Skouloudis et al., 2010; Theron et al., 2012; Vigneau et al., 2015). Vigneau et al. (2015) described the GRI tool to be a soft regulation, with no binding requirements, and therefore, organisations can easily develop their level of compliance to it. In this way, the GRI tool is voluntary (Skouloudis et al., 2010). Also, the GRI tool supports existing regulations to enhance CSR reporting. In Europe, government regulations for CSR reporting often mandate the use of the GRI tool (Fortanier et al. (2011). Therefore, the GRI tool is used for partial regulation of CSR reporting (Theron et al., 2012). Other studies have also viewed the GRI tool as a mechanism for absolute regulation of CSR reporting, which Guthrie et al. (2008) regarded as mandatory CSR reporting in business organisations. Due to its wide acceptance, Lin et al. (2015) state the GRI tool can easily be mandated for CSR reporting. However, this will require the support of rule-making bodies and government agencies to realise this goal (Lin et al., 2015).

\subsubsection{Organisational learning}

Organisational learning is the capability of an organisation to create, acquire, transfer, and integrate knowledge, and to modify its behaviour to reflect the new cognitive situation, to improve performance (Jerez-Gomez et al., 2005). Concerning CSR learning, CSR reporting tools help in knowledge transfer of CSR management, implementation and reporting within organisations (Nikolaeva et al., 2011). In the context of intra-organisational management, the regular application of the GRI tool fosters internal organisational learning among employees about the concept of CSR (Vigneau et al., 2015). For instance, Hedberg et al. (2003)'s study in Swedish companies revealed that stakeholders such as employees, managers, suppliers, 
who were without adequate knowledge of CSR, became better informed about CSR upon managements' adoption of the GRI tool for CSR reporting. The application of the GRI tool helps stakeholders to be aware of requirements and how they can contribute to CSR reporting (Hedberg et al., 2003), as well as increasing their understanding of CSR practices (Lin et al., 2019; Traxler et al., 2018).

\subsection{Finding the Problems of the GRI tool}

\subsubsection{Limited empowerment of the civil regulation}

The role of civil regulation (or civil society groups) is very crucial to the CSR process. They are to provide checks and balances to the CSR performance and the reportage of implemented CSR practices (Brown, de Jong, andLevy, 2009). This is to ensure that CSR can be deepened and progressed in business organisations (Brown, de Jong, andLevy, 2009; Nikolaeva et al., 2011). However, the GRI tool places greater emphasis on the value of social reporting in business organisations and investor communities at the expense of civil regulation (Levy et al., 2010). Therefore, civil society groups are not effectively empowered to check CSR performances reported using the GRI tool. Specifically, the civil regulation is unable to play a more active and assertive role in the CSR discourse (Brown, De Jong, andLessidrenska, 2009; Brown, de Jong, and Levy, 2009; Levy et al., 2010; Nikolaeva et al., 2011). Consequently, the civil organisations are often dissuaded from using the GRI tool for comparison and benchmarking CSR reporters (Brown, De Jong, and Lessidrenska, 2009). This has increased the dangerous influence of the multinational business organisations to use their enhanced economic structures and resources to propel the evolution of the GRI tool towards their interests and ways of thinking (Brown, de Jong, and Levy, 2009). For instance, the multinational business organisations successfully opposed the attempt by the developers of the GRI tool for mandatory CSR reporting and their high intolerance for a GRI system that ranks their CSR performance (Flower, 2015; Levy et al., 2010).

\subsubsection{Lack of standardisation of the GRI indicators/guidelines}

Greater commonality (or standardisation) of the indicators in CSR reporting tools increases the comparability of CSR reports (DiGuilio, 2010). The lack of it is the greatest problem of many CSR reporting tools (Siew, 2015b), particularly the GRI tool where the indicators are less standardised, thereby impairing comparability in a transparent manner (Elving et al., 2015; Lopatta et al., 2014; Wang, 2017). For example, the study of Toppinen et al. (2013) revealed that the GRI-based CSR reports in different organisations were incomparable. By extension, it was difficult to compare the data on GRI indicators across organisations, even 
within the same sector (DiGuilio, 2010; Siew, 2014; Toppinen et al., 2013). Consequently, it became difficult to determine the level of social responsibility in organisations and how quickly they are approaching sustainability using the GRI indicators (Mi Dahlgaard-Park et al., 2009). For practical purposes, this problem can be partly attributed to the data requirements of the GRI tool. Toppinen et al. (2013) 's study of business organisations in the forest sector revealed that much of the information about the GRI indicators are qualitative, and difficult to collect, quantify and standardise across organisations. According to DiGuilio (2010), it was a problem of lack of objectivity; which is more obvious in the society and human right indicators, and many organisations did not comply with these indicators in their CSR reports as a result (Grossi et al., 2015; Siew, 2015b). For GRI items that require quantitative data, some level of subjectivity is still observed. For instance, DiGuilio (2010) revealed that pharmaceutical organisations used different units of measure for their disclosure on "direct energy consumption by energy source", indicative of lack of consistency in GRI indicators. Given that the GRI tool is regularly updated (Moneva et al., 2006), these problems were still not addressed in the latest version of the GRI tool (G4) published in the year 2013 (Elving et al., 2015).

\subsubsection{Limited sector-specific versions of the GRI tool}

As mentioned above, the GRI tool is regularly updated to suit stakeholder needs. Previously updated versions have introduced sector-specific versions in the financial and energy sectors (Alonso-Almeida et al., 2014). Where sector-specific versions were not introduced, supplementary guidelines for sectors such as apparel and footwear, public, and automotive industries were provided (DiGuilio, 2010; Guthrie et al., 2008). The recent addition is "GRI 306: Waste 2020" to enable organisations to embrace circularity by fully understanding and disclosing all waste-related impacts (Global Sustainability Standards Board, 2018). Therefore, while the GRI tool can be credited for sensitivity to sector differences (Tschopp et al., 2014), some sectors are yet to be fully covered. The GRI does not adequately address real estate sector disclosures, especially the vast role of operations and management of real estate assets (Laposa et al., 2010). Fonseca et al. (2014) revealed that the reporting aspect of "prospective temporal orientation", which is critical to CSR in the mining sector, is not covered in the GRI tool. Additionally, Chen et al. (2015) found that the GRI tool does not sufficiently provide information for CSR performance assessment of suppliers in the mining supply chain. The lack of comprehensive sector-specific versions in some sectors has negative impacts. For instance, a global study seeking to understand the adoption of GRI 
across different sectors revealed that the toys, tobacco and rail sectors occupied the lowest ebb in terms of CSR reporting (Alonso-Almeida et al., 2014). The GRI tool does not have specific versions for these sectors. In another study, Barkemeyer et al. (2015) revealed that the GRI reports from the construction sector (without sector-specific version) was leaner and less comprehensive in comparison with the CSR reports from the energy sector, which has section specific versions. Furthermore, as the GRI tool was developed in Europe, it is not applicable to all geographical contexts. Antoni et al. (2006) revealed that factors unique to South Africa were not covered in the GRI tool. Therefore, using the GRI tool for CSR reporting in organisations in developing countries like South Africa may not provide true and context-specific information about implemented CSR practices (Chen et al., 2015).

\subsubsection{Lack of external verification}

External verification is the prerogative of the developers of CSR reporting tools, and also of external assurance organisations such as PwC, KPMG, Ernst \& Young, DNV, and Deloitte (Elving et al., 2015). External verification aids in evaluating quality, continuous improvement, and responsibility of CSR reports, thereby increasing credibility of CSR reporters (or organisations) (Alonso-Almeida et al., 2014). However, there is a limited form of external verification for the GRI-based CSR reports and the processes used to produce them (Brown, De Jong, andLessidrenska, 2009). At best, the developers of GRI tool recommend to CSR reporters to employ external verification towards preparing GRI based CSR reports voluntarily (Jones, Comfort, et al., 2015). However, because such verification is not provided by the developers of GRI tool (Jones, Comfort, et al., 2015), it gives ample opportunity for business organisations to cunningly identify themselves as GRI-based CSR reporters without actually being so (Hedberg et al., 2003). For these organisations, adopting and complying with GRI guidelines do not correspond to high CSR performance (Grossi et al., 2015). On the other hand, especially with the earlier versions of the GRI tool, most organisations report the undeclared level only (Legendre et al., 2013). Due to lack of external verification, the credibility of the GRI tool when used for preparing CSR reports has been subject to queries (Hedberg et al., 2003; Jones, Comfort, et al., 2015; Legendre et al., 2013) and the credibility doubted (Hedberg et al., 2003).

\subsubsection{The bias of the principle of the materiality of the GRI tool}

As defined in the GRI tool, the principle of materiality suggests that business organisations need to tailor their CSR reports to the information needs of their stakeholders as well as the characteristics of their operations (Barkemeyer et al., 2015). While this principle allows 
organisations to decide what to report, it also gives room for bias or loophole. It places those that report all indicators (both positives and negatives) at a disadvantage to those who used the basis of materiality to report only the indicators that make the organisation look good (Brown, De Jong, andLessidrenska, 2009; Elving et al., 2015; Fonseca et al., 2014). This is because the materiality principle in the GRI tool is prone to multiple interpretations by different stakeholders, that often leads to misunderstanding (Antoni et al., 2006) and giving much room for less rigorous CSR reporting (Elving et al., 2015). For instance, the GRI tool provides no concrete characterisation to what it perceives as negative reporting; neither does it provide the criteria for impartiality reporting (Hahn et al., 2014). Therefore, the outcome effectiveness of the GRI tool in terms of allowing meaningful interaction among internal and external stakeholders in business organisations about CSR practices and outcomes (Ainapur et al., 2014) is low (Barkemeyer et al., 2015; Toppinen et al., 2013). According to Barkemeyer et al. (2015), this reduces CSR reporting to the level of management fad in organisations - which is to potentially manipulate the readers' perceptions (Hahn et al., 2014).

\subsubsection{Limited use of the GRI tool in small organisations}

Arena et al. (2012) revealed that despite the increasing global impact of small organisations in the conduct of business, they are unable to communicate social responsibility (or sustainability) strategy adequately resulting in their CSR reports. The reason is that most CSR reporting tools, including the GRI tool, were developed for use in large organisations. Particularly, the GRI tool, which is more widespread, has barely inculcated CSR requirements of small organisations (Arena et al., 2012). Although the developer of the GRI tool has been engaging the small organisations towards CSR reporting (Levy et al., 2010), the human and financial resource requirements for implementing the use of the GRI tool is beyond the capacity of small organisations (Baumann-Pauly, 2013). Brown, De Jong, and Lessidrenska (2009) revealed that small organisations find the GRI guidelines too complicated and demanding, the result of which has been little or no CSR reporting in small organisations. It was mentioned previously that the GRI tool indicators are less standardised for comparability purposes. This problem is greater in smaller organisations. As demonstrated in small organisations in the German manufacturing sector, it is difficult to determine accurate sustainability performance due to varied units of measurement of individual GRI indicators (Steinhöfel et al., 2019).

\subsection{Standards}




\subsubsection{Benefits}

The benefits of CSR reporting tools in the standards class are often identified in many studies (Göbbels et al., 2003a; Theron et al., 2012), but not the benefits of using them for CSR reporting in the organisation context. To bridge this gap, Sartor et al. (2016) identified the benefits of the SA8000 CSR reporting tool. It was found that the benefits of using this tool are dependent on the business focus in the reporting business organisation. It means, for instance, the benefits of using the tool in a manufacturing business must be manufacturing related. For instance, Marakova et al. (2015) revealed that enterprise organisations in Poland use standards, especially the ISO standards for CSR reporting (Toppinen et al., 2015), to obtain certification and drive business competitiveness. For the ISO 26000, Hahn (2013) revealed that it is useful for internal and external analyses, to provide the starting point for the implementation of sustainability strategies, especially at initial stages of CSR implementation.

\subsubsection{Implementation}

By implementation, it means the crucial steps in place towards the actual use of CSR reporting tools. For ISO 26000 in the standards class, Zinenko et al. (2015b) stated that a strategy for implementation is necessary to ensure success. As revealed by Ferrante et al. (2010) in their study of strategies for introducing ISO 26000 tool in public organisations in Italy and Switzerland, they concluded that a top-down approach, accompanied with negotiation, is necessary for introducing and implementing the tool. The top-down approach encompasses the role and commitment of leaders in organisations in the implementation process. This is coupled with discussions and bargaining with local participants and the organisational members. Alternatively, according to Ferrante et al. (2010), the top-down approach can be integrated with a bottom-up approach. The latter approach promotes equal participation of all stakeholders in the implementation of CSR reporting tools within the organisation.

\subsubsection{Factors affecting implementation}

From a strategic perspective, the implementation of CSR reporting tools, regardless of classification, are influenced by certain factors. Generally, they could be factors relating to the demands and wishes of customers, the attitude of a company's management, the market position of the organisation, tangible and intangible characteristics of the reporting tool (Moratis and Tatang Widjaja, 2014). Furthermore, when organisations have a previous favourable experience with the use of a reporting tool in the standards class, say ISO 14001, 
they are encouraged to adopt newer or more recent versions, say ISO 26000 (Zinenko et al., 2015b). In consequence, the experience gained from the implementation of the previous can be adapted in the implementation of new. Like the GRI tool, the use of CSR reporting tools in the standards class comes with challenges for the reporting business organisations. From an account of the use of the SA8000 tool, Sartor et al. (2016) classified these challenges into obstacles faced in getting a certification, obstacles faced in the ongoing management of certification and obstacles faced in obtaining and managing the certification. In corroboration, Zinenko et al. (2015b) described certification as one of the barriers which deter organisations from implementing CSR reporting tools in the standards class.

\subsection{Ratings and Indices}

\subsubsection{Complementing use}

Of note is that the CSR reporting tools in the ratings and indices class appear to complement the GRI tool in the framework class. An example is the KiwiGrow tool, which is based on 28 indicators covering social, economic, environmental and cultural dimensions of health and sustainability. The KiwiGrow tool was developed to deemphasise on corporate business reporting that is common with the GRI tool, while at the same time, to emphasise on the ecosystem health of business organisations, communities, households, neighbourhoods, cities and regions (Luckman, 2006). According to Rapport et al. (2006), the ecosystem health approach is important because it enables the determination of overall environmental viability and pressures from human activity that threatens the viability. However, KiwiGrow and others such as the Pressure-State-Response (PSR) model for State of Environment Reporting (Rapport et al., 2006) are not globalised like the GRI tool, thereby limiting their use and acceptability.

\subsubsection{Community use}

Furthermore, CSR reporting tools in the ratings and indices class are very useful at the community level. Many rating tools, which are originally focused on the sustainability performance rating of buildings such as BREAM, LEED, and Green Star are increasingly adapted for reporting about the ecosystem health of communities (Siew, 2014). The tools provide guidelines for ecosystem health reporting across infrastructure projects, and their use by building owners and operators is a demonstration of commitment to CSR in the built environment (YJ Siew et al., 2013). At the community level, these tools can help tackle a range of sustainability issues such as pollution and biodiversity more synergistically (Siew, 
2014). Also, there is more scope for these tools to cover community-related issues such as age-friendliness features in the environment (Siew et al., 2016).

\section{Discussion}

This study has investigated the use of CSR reporting tools in the frameworks, standards, and ratings and indices classes. The study obtained researchers' accounts of the subject by undertaking a systematic literature review of journal papers published from 2001-2016. The researchers' accounts are a departure from existing studies and therefore offered the opportunity to produce a more holistic knowledge of the collective use of CSR reporting tools according to their classifications as discussed below.

Of all the classes of CSR reporting tools, the findings revealed that researchers focused mostly on the GRI tool in the framework class based on the number of publications. Interestingly, the GRI tool is widely accepted and used for CSR reporting in practice. Also, the findings revealed the plethora of problems bedevilling the GRI tool. The problems identified include, but are not limited to, limited empowerment of civil regulation, lack of standardisation of GRI tool indicators and limited sector-specific versions of the tool. Therefore, the focus of researchers on the GRI tool speculate an attempt to address the plethora of problems through research. In previous research, the focus of researchers has been very conceptual and limited to subjective criticism of the conceptualisation and design of the GRI tool (e.g. (Dingwerth et al., 2010)). As a result, such accounts have not highlighted the problems that could be encountered using the GRI tool in greater certainty.

By identifying the problems, this study indicated how the GRI tool affects CSR reporting in practice. Take the problems of 'limited empowerment of civil regulation' and 'lack of external verification for example: both leave CSR reporters who use the GRI tool unchecked, which gives room for less transparent and accountable CSR reports. Furthermore, this study revealed new aspects that the GRI tool could be used when implemented in practice. The GRI tool was conceptualised and designed for voluntary CSR reporting. However, based on the findings, the GRI tool could be used for both partial and mandatory CSR regulation. This is possible by strictly following the GRI tool guidelines in preparing CSR reports in either regulation (Vigneau et al., 2015). However, the mandatory regulation additionally requires government law that specifies the use of the GRI tool for CSR reporting.

Furthermore, fewer studies analysed CSR reporting tools in the standards and ratings and indices classes. This pointed to less researcher interest in the tools in either class (Moratis and 
Tatang Widjaja, 2014) compared with the GRI tool in the framework class. To apply some logic, researchers are more likely to design research investigations around the CSR reporting tools that are commonly used than those that are not. If so, less researcher interest is also a confirmation of the limited extent to which CSR reporting tools in the standards and, ratings and indices classes, are used in practice. As a result, the studies analysed focused on how to increase the implementation of CSR reporting tools in both classes in practice. For the CSR reporting tools in the standards class, the best approach of implementation is to incorporate them into the existing business or corporate strategy, especially the ISO 26000 tool (Ferrante et al., 2010). Apart from increasing seamless implementation, this approach has an advantage of cascading the objective of socially responsible practices throughout the organisation (Hahn, 2013; Licandro et al., 2019; Swiatkiewicz, 2017). How to increase the implementation of CSR reporting tools in the ratings and indices class is to use them to complement the GRI tool in the framework class. The tools in the ratings and indices class focus on the ecosystem health in communities which is de-emphasised in the GRI tool (Jones, Comfort, et al., 2015). Instead, the GRI tool is focused on reporting the business impacts in practice. Therefore, the GRI tool and a rating and indices tool such as LEED-ND can be used for CSR reporting in a single CSR report.

The complementariness of CSR reporting tools in different classes feeds into the ongoing narrative about the harmonisation of CSR reporting tools (Einwiller et al., 2016; Ortiz et al., 2014; Siew, 2015b; Tschopp et al., 2014). According to Tschopp et al. (2014), harmonised CSR reporting tools provide decision makers with CSR reports they can easily compare and contrast, towards making better socially responsible decisions. Therefore, harmonised CSR tools provide a common language of best CSR practices that is understood across organisations and stakeholders (Göbbels et al., 2003a; Jose, 2017). An empirical study by Zinenko et al. (2015b) specified the harmonisation of the UNGC, GRI and ISO 26000 tools for CSR reporting incrementally. The study specified that the UNGC tool can be used to establish general goals and codes of conduct as a first step, followed by ISO 26000 for implementing and reviewing CSR goals, and lastly, the GRI tool for continuing improvement in order to report on the CSR outcomes for all the different stakeholders (Zinenko et al., 2015b). The findings about the complementariness of the GRI tool and ratings and indices tools in the current study extend the narrative about harmonisation of CSR reporting tools, and some recommendations in this regard are provided in Table 3. 
Table 3: Summary of recommendations for the use of CSR reporting tools based on the classification

\begin{tabular}{|c|c|c|c|}
\hline $\begin{array}{l}\text { Class of CSR } \\
\text { reporting tools }\end{array}$ & Definition & Typical examples & $\begin{array}{l}\text { Recommendation for use } \\
\text { based on classification }\end{array}$ \\
\hline Frameworks class & $\begin{array}{l}\text { The CSR reporting tools in } \\
\text { this class are principles, } \\
\text { initiatives or guidelines which } \\
\text { assist in disclosure efforts }\end{array}$ & $\begin{array}{l}\text { GRI, UNGC, IIRC and } \\
\text { CDP are typical } \\
\text { examples. }\end{array}$ & $\begin{array}{l}\text { - The GRI tool is the most } \\
\text { reported in research } \\
\text { - Researchers' accounts } \\
\text { revealed a plethora of } \\
\text { problems affecting the use } \\
\text { of the GRI tool } \\
\text { - The problems affect CSR } \\
\text { reporting practice } \\
\text { negatively } \\
\text { - The use of the GRI tool } \\
\text { could achieve mandatory } \\
\text { CSR reporting and } \\
\text { increase employees' } \\
\text { knowledge of CSR }\end{array}$ \\
\hline Standards class & $\begin{array}{l}\text { The CSR reporting tools in } \\
\text { this class guide disclosure } \\
\text { efforts, but in the form of } \\
\text { formal documentation that } \\
\text { spells out the requirements, } \\
\text { specifications or } \\
\text { characteristics for ensuring } \\
\text { that sustainability efforts are } \\
\text { consistently achieved }\end{array}$ & $\begin{array}{l}\text { ISO } 26000, \text { AA } 1000, \\
\text { ISO } 4001, \text { OECD } \\
\text { guidelines are typical } \\
\text { examples. The ISO } \\
26000 \text { is most reported } \\
\text { in research }\end{array}$ & $\begin{array}{l}\text { - The ISO } 26000 \text { is the most } \\
\text { reported in research } \\
\text { - The ISO } 26000 \text { can help } \\
\text { incorporate CSR into } \\
\text { corporate strategy }\end{array}$ \\
\hline $\begin{array}{l}\text { Ratings and indices } \\
\text { class }\end{array}$ & $\begin{array}{l}\text { The CSR reporting tools in } \\
\text { this class evaluate the social } \\
\text { responsibility contributions to } \\
\text { sustainable development. }\end{array}$ & $\begin{array}{l}\text { The tools for evaluation } \\
\text { in buildings include } \\
\text { BREEAM, LEED and } \\
\text { CASBEE. The tools for } \\
\text { evaluation in the } \\
\text { communities include } \\
\text { HQE }^{2} \mathrm{R} \text { and EcoCity }\end{array}$ & $\begin{array}{l}\text { - The CSR reporting tools } \\
\text { in this class emphasise } \\
\text { ecological aspects of CSR } \\
\text { in the communities such } \\
\text { as biodiversity, sustainable } \\
\text { building performance, } \\
\text { age-friendliness and } \\
\text { ecosystem health in } \\
\text { communities } \\
\text { - Complementing CSR } \\
\text { reporting tools in other } \\
\text { classes, especially the GRI } \\
\text { tool } \\
\end{array}$ \\
\hline
\end{tabular}

\section{Conclusion and recommendations}

This study employed a systematic literature review of eighty-one (81) journal publications to reveal the use of CSR reporting tools. The study departed from the analyses of CSR reports and focused researchers' viewpoints on the use of CSR reporting tools based on their classification (e.g. frameworks, standards and, rating and indices classes). As a result, the study produced a more holistic knowledge of the collective use of CSR reporting tools as concluded below.

Although the GRI tool in the framework class is widely accepted and used for CSR reporting in practice, it is associated with a plethora of problems. Therefore, researchers focused mainly on the GRI tool to address the problems through research. The problems that were 
identified in this study indicate a negative impact of the GRI tool on CSR reporting practice. Furthermore, the new aspects that the GRI tool could be used for, include organisational learning and CSR regulation. Regarding CSR regulation, the GRI tool, which was designed for voluntary CSR reporting, could now be used for both partial and mandatory CSR reporting. This study concluded that researchers' focus on the GRI tool is to address its plethora of problems and to reveal new aspects of its use in practice.

The CSR reporting tools in the standards, and ratings and indices classes are not commonly used for CSR reporting, especially when compared to the GRI tool in the framework class. As a result, they attract less researcher interest, which is limited to increasing the implementation of CSR reporting tools in both classes. To increase implementation, the CSR reporting tools in the standards class need to be incorporated into corporate strategy, while the reporting tools need to be implemented to complement the GRI tool. The potential for complementariness deduced in this study contribute to the literature on the harmonisation of CSR reporting tools. This study concluded that less researcher focus on CSR reporting tools in the standards, and ratings and indices classes, is because they are not commonly used for CSR reporting, and consequently provide the research motivation aimed at increasing the implementation of CSR reporting tools in both classes.

This research is significant by revealing the commonly used CSR reporting tools according to their classifications and the impact on CSR reporting. CSR reporters that use the GRI tool should be cognisant of the associated problems but also explore the new uses of the tool to produce better CSR reporting. Where ecological and community health are prioritised, the GRI tool should be combined with any of the ratings and indices tools. Also, the CSR reporting tools in the standards class should be implemented only after incorporating any of them in the corporate strategy to ensure seamless implementation. However, the scope of researchers' accounts is limited to review of literature, and not directly interviewing academic scholars. Also, the reviewed publications covered a period of close to two decades until a relatively recent period in 2016. The period from 2016 till present date may encompass new insights worthy of investigation.

Declaration of Competing Interest

There is no conflict of interest in this research

References

Adams, C., \& Zutshi, A. (2004). Corporate social responsibility: why business should act responsibly and be accountable. Australian accounting review, 14(34), 31-39. 
Ainapur, R., Rao, B. R., \& lacocca, L. (2014). Prominence of stakeholders in designing sustainability reporting practices based on G4 Guidelines. International Journal of Management, 11(5), 7075.

Alazzani, A., \& Wan-Hussin, W. N. (2013). Global Reporting Initiative's environmental reporting: A study of oil and gas companies. Ecological indicators, 32, 19-24.

Alonso-Almeida, M., Llach, J., \& Marimon, F. (2014). A closer look at the 'Global Reporting Initiative'sustainability reporting as a tool to implement environmental and social policies: A worldwide sector analysis. Corporate Social Responsibility and Environmental Management, 21(6), 318-335.

Angelakoglou, K., \& Gaidajis, G. (2015). A review of methods contributing to the assessment of the environmental sustainability of industrial systems. Journal of Cleaner Production, 108, 725747.

Antoni, M., \& Hurt, Q. (2006). Applying the Global Reporting Initiative (GRI) for public bodies in the South African context: the eThekwini experience. Development Southern Africa, 23(2), 251263.

Arena, M., \& Azzone, G. (2012). A process-based operational framework for sustainability reporting in SMEs. Journal of Small Business and Enterprise Development, 19(4), 669-686.

Ayuso, S., Roca, M., Arevalo, J. A., \& Aravind, D. (2016). What determines principle-based standards implementation? Reporting on global compact adoption in Spanish firms. Journal of business ethics, 133(3), 553-565.

Barkemeyer, R., Preuss, L., \& Lee, L. (2015). On the effectiveness of private transnational governance regimes-Evaluating corporate sustainability reporting according to the Global Reporting Initiative. Journal of World Business, 50(2), 312-325.

Baumann-Pauly, E. A. (2013). Organizing corporate social responsibility in small and large firms: Size matters. Journal of Business Ethics, 115(4), 693-705.

Brown, H. S., De Jong, M., \& Lessidrenska, T. (2009). The rise of the Global Reporting Initiative: a case of institutional entrepreneurship. Environmental Politics, 18(2), 182-200.

Brown, H. S., de Jong, M., \& Levy, D. L. (2009). Building institutions based on information disclosure: lessons from GRI's sustainability reporting. Journal of Cleaner Production, 17(6), 571-580.

Campopiano, G., \& De Massis, A. (2015). Corporate social responsibility reporting: A content analysis in family and non-family firms. Journal of business ethics, 129(3), 511-534.

Carr, E. R., Wingard, P. M., Yorty, S. C., Thompson, M. C., Jensen, N. K., \& Roberson, J. (2007). Applying DPSIR to sustainable development. International Journal of Sustainable Development \& World Ecology, 14(6), 543-555.

Chantziaras, A., Dedoulis, E., Grougiou, V., \& Leventis, S. (2020). The impact of religiosity and corruption on CSR reporting: The case of US banks. Journal of Business Research, 109, 362374.

Chen, L., Feldmann, A., \& Tang, O. (2015). The relationship between disclosures of corporate social performance and financial performance: Evidences from GRI reports in manufacturing industry. International Journal of Production Economics, 170, 445-456.

Cohen, M. (2017). A systematic review of urban sustainability assessment literature. Sustainability, 9(11), 2048.

Diez-Cañamero, B., Bishara, T., Otegi-Olaso, J. R., Minguez, R., \& Fernández, J. M. (2020). Measurement of Corporate Social Responsibility: A Review of Corporate Sustainability Indexes, Rankings and Ratings. Sustainability, 12(5), 2153.

DiGuilio, L. (2010). The second round of G3 reports: is triple bottom line reporting becoming more comparable? Journal of Business \& Economics Research, 8(9), 59.

Dingwerth, K., \& Eichinger, M. (2010). Tamed transparency: How information disclosure under the global reporting initiative fails to empower. Global Environmental Politics, 10(3), 74-96.

Dumay, J., Guthrie, J., \& Farneti, F. (2010). GRI sustainability reporting guidelines for public and third sector organizations: A critical review. Public Management Review, 12(4), 531-548. 
Einwiller, S., Ruppel, C., \& Schnauber, A. (2016). Harmonization and differences in CSR reporting of US and German companies: Analyzing the role of global reporting standards and country-oforigin. Corporate Communications: An International Journal, 21(2), 230-245.

Elo, S., \& Kyngäs, H. (2008). The qualitative content analysis process. Journal of advanced nursing, 62(1), 107-115.

Elving, W. J., Golob, U., Podnar, K., Ellerup-Nielsen, A., Thomson, C., Knebel, S., \& Seele, P. (2015). Quo vadis GRI? A (critical) assessment of GRI 3.1 A+ non-financial reports and implications for credibility and standardization. Corporate Communications: An International Journal, 20(2), 196-212.

Ferrante, A., Gandolfi, A., \& Meneguzzo, M. (2010). Anticipatory strategies for introducing ISO 26000 in 2010: a comparison between the Italian and Swiss systems of public administration. Economia Aziendale Online, 1(3), 311-321.

Flower, J. (2015). The international integrated reporting council: a story of failure. Critical Perspectives on Accounting, 27, 1-17.

Fonseca, A., McAllister, M. L., \& Fitzpatrick, P. (2014). Sustainability reporting among mining corporations: a constructive critique of the GRI approach. Journal of Cleaner Production, 84, 70-83.

Fortanier, F., Kolk, A., \& Pinkse, J. (2011). Harmonization in CSR reporting. Management International Review, 51(5), 665-696.

Gingerich, E. (2010). Engaging Multidisciplinary University Students in" Triple Bottom Line" Reporting: Using Global Reporting Initiative Metrics Inside the Classroom. International Journal of Interdisciplinary Social Sciences, 5(7)

Global Sustainability Standards Board. (2018). Review of GRI Waste Disclosures. Retrieved May 20 2020 from https://www.globalreporting.org/standards/media/1970/waste-disclosuresreview pwg-member-bios.pdf

Göbbels, M., \& Jonker, J. (2003a). AA1000 and SA8000 compared: a systematic comparison of contemporary accountability standards. Managerial Auditing Journal, 18(1), 54-58.

Göbbels, M., \& Jonker, J. (2003b). AA1000 and SA8000 compared: a systematic comparison of contemporary accountability standards. Managerial Auditing Journal

González-Rodríguez, M. R., Díaz-Fernández, M. C., \& Simonetti, B. (2015). The social, economic and environmental dimensions of corporate social responsibility: The role played by consumers and potential entrepreneurs. International Business Review, 24(5), 836-848.

Gray, R., \& Kouhy, R. L. (1995). S., 1995. Corporate social and environmental reporting: a review of the literature and a longitudinal study of UK disclosure. Accounting, Auditing and Accountability Journal, 8(2), 47-77.

Grossi, G., Papenfuß, U., Tremblay, M.-S., Greiling, D., Traxler, A. A., \& Stötzer, S. (2015). Sustainability reporting in the Austrian, German and Swiss public sector. International Journal of Public Sector Management, 28(4/5), 404-428.

Gupta, V., \& Lehal, G. S. (2011). Automatic keywords extraction for Punjabi language. International Journal of Computer Science Issues (IJCSI), 8(5), 327.

Guthrie, J., \& Farneti, F. (2008). GRI sustainability reporting by Australian public sector organizations. Public Money and management, 28(6), 361-366.

Hahn, R. (2013). ISO 26000 and the standardization of strategic management processes for sustainability and corporate social responsibility. Business Strategy and the Environment, 22(7), 442-455.

Hahn, R., \& Lülfs, R. (2014). Legitimizing negative aspects in GRI-oriented sustainability reporting: A qualitative analysis of corporate disclosure strategies. Journal of Business Ethics, 123(3), 401420.

Hedberg, C. J., \& Von Malmborg, F. (2003). The global reporting initiative and corporate sustainability reporting in Swedish companies. Corporate Social Responsibility and Environmental Management, 10(3), 153-164. 
James, M. L. (2013). Sustainability and integrated reporting: Opportunities and strategies for small and midsize companies. The Entrepreneurial Executive, 18, 17.

Jerez-Gomez, P., Céspedes-Lorente, J., \& Valle-Cabrera, R. (2005). Organizational learning capability: a proposal of measurement. Journal of business research, 58(6), 715-725.

Jones, P., Comfort, D., \& Hillier, D. (2015). Managing materiality: a preliminary examination of the adoption of the new GRI G4 guidelines on materiality within the business community. Journal of Public Affairs

Jones, P., Hillier, D., \& Comfort, D. (2015). Corporate water stewardship. Journal of Environmental Studies and Sciences, 5(3), 272-276.

Jose, T. (2017). Need for Harmonisation of Sustainability Reporting Standards. Journal of Finance and Economics, 5(6), 253-258.

Kaspereit, T., \& Lopatta, K. (2016). The value relevance of SAM's corporate sustainability ranking and GRI sustainability reporting in the European stock markets. Business ethics: A European review, 25(1), 1-24.

Knoepfel, I. (2001). Dow Jones Sustainability Group Index: a global benchmark for corporate sustainability. Corporate Environmental Strategy, 8(1), 6-15.

Kolk, A. (2011). Harmonization in CSR reporting MNEs and global CSR standards. Management International Review, 51(5), 665-696.

Laposa, S., \& Villupuram, S. (2010). Corporate real estate and corporate sustainability reporting: an examination and critique of current standards. Journal of Sustainable Real Estate, 2(1), 2349.

Legendre, S., \& Coderre, F. (2013). Determinants of GRI G3 application levels: the case of the fortune global 500. Corporate Social Responsibility and Environmental Management, 20(3), 182-192.

Levy, D. L., Brown, H. S., \& De Jong, M. (2010). The Contested politics of corporate governance the case of the global reporting initiative. Business \& Society, 49(1), 88-115.

Li, Y., Chen, X., Wang, X., Xu, Y., \& Chen, P.H. (2017). A review of studies on green building assessment methods by comparative analysis. Energy and Buildings, 146, 152-159.

Licandro, O. D., Ramírez García, A. G., Alvarado-Peña, L. J., Vega Osuna, L. A., \& Correa, P. (2019). Implementation of the ISO 26000 Guidelines on Active Participation and Community Development. Social Sciences, 8(9), 263.

Lin, I., Chang, O., \& Chang, C. (2015). Perceptions of GRI reporting guidelines. International Journal of Sustainability Policy and Practice, 9(4), 35-54.

Lin, Y.-T., \& Liu, N.-C. (2019). Corporate Citizenship and Employee Outcomes: Does a HighCommitment Work System Matter? Journal of business ethics, 156(4), 1079-1097.

Linneberg, M. S., \& Thorup-Jensen, L. (2014). Towards strategic CSR in multinational corporations. Danish Journal of Management and Business, 78(2)

Lock, I., \& Seele, P. (2015). Analyzing sector-specific CSR reporting: Social and environmental disclosure to investors in the chemicals and banking and insurance industry. Corporate Social Responsibility and Environmental Management, 22(2), 113-128.

Lopatta, K., \& Jaeschke, R. (2014). Sustainability reporting at German and Austrian universities. International Journal of Education Economics and Development, 5(1), 66-90.

Luckman, P. G. (2006). KiwiGrow-a new approach to sustainable development reporting. Australasian Journal of Environmental Management, 13(4), 261-271.

Marakova, V., Lament, M., \& Wolak-Tuzimek, A. (2015). Reporting standards in socially responsible enterprises. Економічний часопис-XXI(9-10), 56-59.

Mi Dahlgaard-Park, S., Isaksson, R., \& Steimle, U. (2009). What does GRI-reporting tell us about corporate sustainability? The TQM Journal, 21(2), 168-181.

Mok, K. Y., Shen, G. Q., \& Yang, J. (2015). Stakeholder management studies in mega construction projects: A review and future directions. International Journal of Project Management, 33(2), 446-457. 
Moneva, J. M., Archel, P., \& Correa, C. (2006). GRI and the camouflaging of corporate unsustainability. Paper presented at the Accounting forum.

Moratis, L., \& Tatang Widjaja, A. (2014). Determinants of CSR standards adoption: exploring the case of ISO 26000 and the CSR performance ladder in The Netherlands. Social Responsibility Journal, 10(3), 516-536.

Moratis, L., \& Widjaja, A. T. (2014). Determinants of CSR standards adoption: exploring the case of ISO 26000 and the CSR performance ladder in The Netherlands. Social Responsibility Journal

Morioka, S. N., \& de Carvalho, M. M. (2016). A systematic literature review towards a conceptual framework for integrating sustainability performance into business. Journal of Cleaner Production, 136, 134-146.

Nikolaeva, R., \& Bicho, M. (2011). The role of institutional and reputational factors in the voluntary adoption of corporate social responsibility reporting standards. Journal of the Academy of Marketing Science, 39(1), 136-157.

Nikolaou, I. E., Tsalis, T. A., \& Evangelinos, K. I. (2019). A framework to measure corporate sustainability performance: A strong sustainability-based view of firm. Sustainable Production and Consumption, 18, 1-18.

Olanipekun, A. O., Chan, A. P., Xia, B. P., \& Ameyaw, E. E. (2017). Indicators of owner commitment for successful delivery of green building projects. Ecological indicators, 72, 268-277.

Ortiz, E., \& Marín, S. (2014). Global Reporting Initiative (GRI) as recognized guidelines for sustainability reporting by Spanish companies on the IBEX 35: Homogeneity in their framework and added value in the relationship with financial entities. Intangible Capital, 10(5), 855-872.

Rapport, D. J., \& Singh, A. (2006). An ecohealth-based framework for state of environment reporting. Ecological Indicators, 6(2), 409-428.

Sartor, M., Orzes, G., Di Mauro, C., Ebrahimpour, M., \& Nassimbeni, G. (2016). The SA8000 social certification standard: Literature review and theory-based research agenda. International Journal of Production Economics, 175, 164-181.

Sharifi, A., \& Murayama, A. (2013). A critical review of seven selected neighborhood sustainability assessment tools. Environmental Impact Assessment Review, 38, 73-87.

Siew, R. (2015a). A review of corporate sustainability reporting tools (SRTs). Journal of environmental management, 164, 180-195.

Siew, R. Y. (2015b). A review of corporate sustainability reporting tools (SRTs). Journal of environmental management, 164, 180-195.

Siew, R. Y., \& Siew, R. Y. (2016). Assessing the readiness of sustainability reporting tools (SRTs) for an age-friendly built environment. Journal of Financial Management of Property and Construction, 21(2), 122-136.

Siew, R. Y. J. (2014). A review of sustainability reporting tools (SRTs) for Communities. International Journal of Sustainable Construction Engineering and Technology, 5(2), 39-52.

Skouloudis, A., Evangelinos, K., \& Kourmousis, F. (2010). Assessing non-financial reports according to the Global Reporting Initiative guidelines: evidence from Greece. Journal of Cleaner Production, 18(5), 426-438.

Soyka, P. A. (2013). The international integrated reporting council (IIRC) integrated reporting framework: Toward better sustainability reporting and (Way) beyond. Environmental Quality Management, 23(2), 1-14.

Soysa, I. (2014). Global environmental and sustainability reporting frameworks for mining projects in developed and developing countries. Australian Resources and Energy Law Journal, 33(2), 205.

Steinhöfel, E., Galeitzke, M., Kohl, H., \& Orth, R. (2019). Sustainability Reporting in German Manufacturing SMEs. Paper presented at the 16th Global Conference on Sustainable Manufacturing-Sustainable Manufacturing for Global Circular Economy. Proc. Manuf. 
Swiatkiewicz, O. (2017). Linking CSR to strategy: a practical view. Foundations of Management, 9(1), 299-316.

Tam, V. W., Karimipour, H., Le, K. N., \& Wang, J. (2018). Green neighbourhood: Review on the international assessment systems. Renewable and Sustainable Energy Reviews, 82, 689-699.

Theron, C., \& MacKenzie, S. (2012). Setting standards for sustainable business Introduction. Environmental Law \& Management, 24, 304-308. https://www.academia.edu/6214955/Setting standards for sustainable business Introduc tion

Tokarčíková, E., Bartošová, V., \& Poniščiaková, O. (2014). CORPORATE SOCIAL RESPONSIBILITY REPORTING.

Toppinen, A., Hänninen, V., \& Lähtinen, K. (2015). ISO 26000 in the assessment of CSR communication quality: CEO letters and social media in the global pulp and paper industry. Social Responsibility Journal, 11(4), 702-715.

Toppinen, A., \& Korhonen-Kurki, K. (2013). Global Reporting Initiative and social impact in managing corporate responsibility: a case study of three multinationals in the forest industry. Business ethics: A European review, 22(2), 202-217.

Toppinen, A., Li, N., Tuppura, A., \& Xiong, Y. (2012). Corporate Responsibility and Strategic Groups in the Forest-based Industry: Exploratory Analysis based on the Global Reporting Initiative (GRI) Framework. Corporate Social Responsibility and Environmental Management, 19(4), 191-205.

Traxler, A. A., Greiling, D., \& Hebesberger, H. (2018). GRI Sustainability Reporting by INGOs: A way forward for improving accountability? VOLUNTAS: International Journal of Voluntary and Nonprofit Organizations, 1-17.

Tschopp, D., \& Nastanski, M. (2014). The harmonization and convergence of corporate social responsibility reporting standards. Journal of business ethics, 125(1), 147-162.

Turner, G., Vourvachis, P., \& Woodward, T. (2006). Heading towards sustainability reporting: A pilot study into the progress of embracing the global reporting initiative in the United Kingdom. Journal of Applied Accounting Research, 8(2), 41-70.

Vigneau, L., Humphreys, M., \& Moon, J. (2015). How do firms comply with international sustainability standards? Processes and consequences of adopting the global reporting initiative. Journal of business ethics, 131(2), 469-486.

Wang, X. (2017). Regulatory compliance as fulfilment of corporate social responsibility: an interpretative textual analysis on sustainability reports of two Chinese listed agribusinesses. Asian Journal of Sustainability and Social Responsibility, 2(1), 23-40.

Withers, S., \& Demediuk, P. (2014). Sustainability Reporting Guidelines: Which to Choose? International Journal of Sustainability in Economic, Social and Cultural Context, 9, 44-60. http://ijsesc.cgpublisher.com/product/pub.273/prod.68

YJ Siew, R., CA Balatbat, M., \& G. Carmichael, D. (2013). A review of building/infrastructure sustainability reporting tools (SRTs). Smart and Sustainable Built Environment, 2(2), 106-139.

Yongvanich, K., \& Guthrie, J. (2004). The Australian mining industry's sustainability reporting: An examination of legitimation strategies. Paper presented at the 4th Asia Pacific Interdisciplinary Research in Accounting Conference.

Zhang, J., Li, H., Olanipekun, A. O., \& Bai, L. (2019). A successful delivery process of green buildings: the project owners' view, motivation and commitment. Renewable energy, 138, 651-658.

Zinenko, A., Rovira, M. R., \& Montiel, I. (2015a). The fit of the social responsibility standard ISO 26000 within other CSR instruments. Sustainability Accounting, Management and Policy Journal

Zinenko, A., Rovira, M. R., \& Montiel, I. (2015b). The fit of the social responsibility standard ISO 26000 within other CSR instruments: Redundant or complementary? Sustainability Accounting, Management and Policy Journal, 6(4), 498-526. 


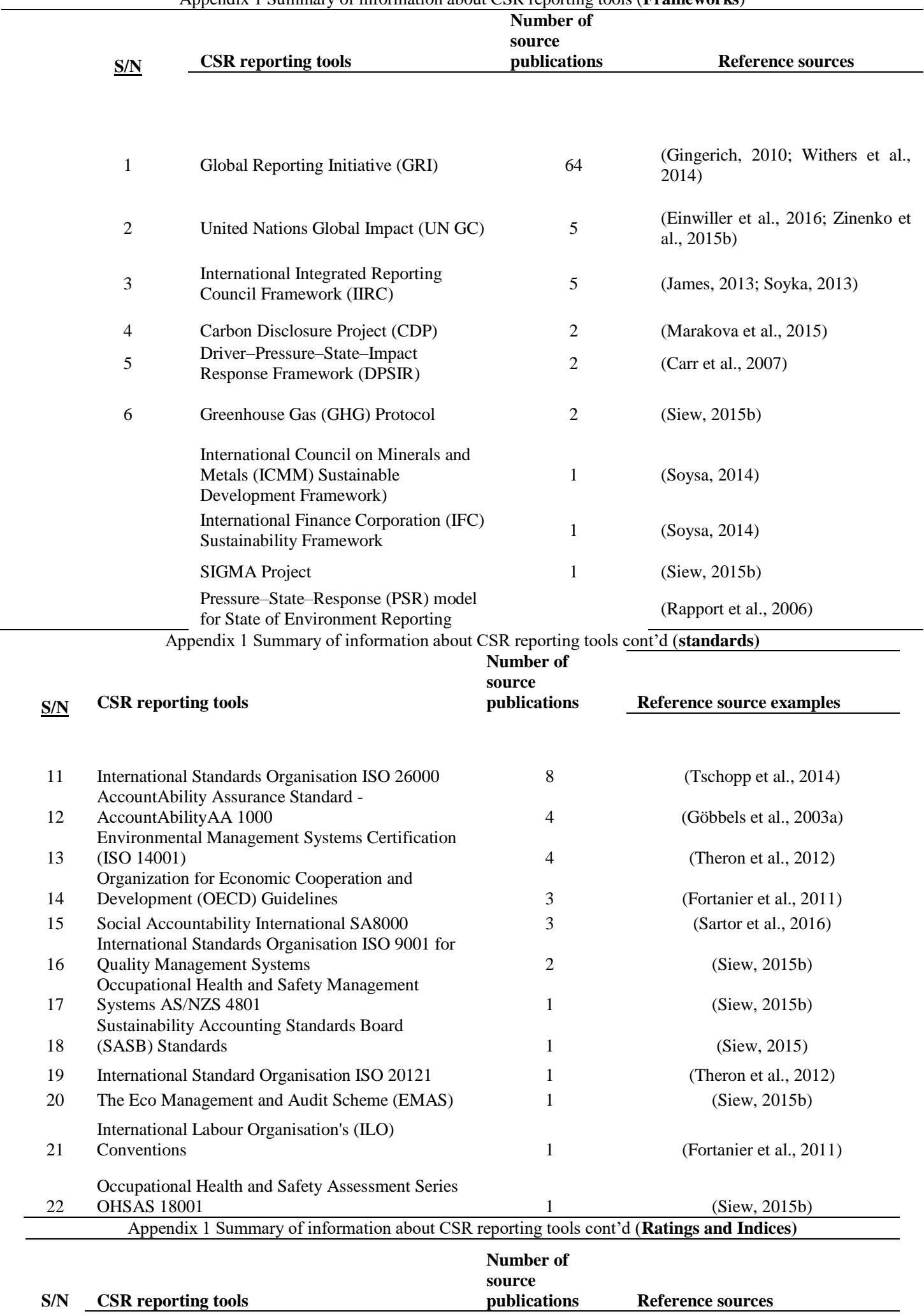

Building Research Establishment Environmental

23

ment Method (BREAM)

Comprehensive Assessment System for

Building Environmental Efficiency- for Urban

24 Development (CASBEEUD)

25 Green Star

Leadership in Energy and Environmental Design

26

(LEED)
(Siew, 2014) 
Dow Jones Indices

(Knoepfel, 2001)

KiwiGrow Ecosystem Model

(Luckman, 2006)

EcoCity

Göbbels et al., 2003a)

The sustainable transformation of a

neighbourhood (HQE2R)

(Göbbels et al., 2003a)

Hong Kong Building Environmental

Assessment Method (HK-BEAM)

(YJ Siew et al., 2013)

Building Sustainability Index (BASIX)

(YJ Siew et al., 2013)

National Australian Built Environment Rating

System (NABERS)

(YJ Siew et al., 2013)

Energy Star

(YJ Siew et al., 2013)

A Sustainability Poverty Infrastructure Routine for Evaluation (ASPIRE)

(YJ Siew et al., 2013)

Australian Green Infrastructure Council (AGIC)

(YJ Siew et al., 2013)

Other ratings and indices are KLD Global

Sustainability Index (GSI) and Index Series,

Empowering Responsible Investment (EIRIS),

Sustainable Asset Management (SAM),

Academic Social Responsibility (ASR), Modern

Index Strategy Indexes (MSCI), FTSE4Good

Index Series, Bloom Centre for Sustainability 